\title{
JURNAL REDOKS
}

Pelindung

Muhammad Firdaus,S.T,M.T

(Dekan Fakultas Teknik Universitas PGRI Palembang)

\author{
Pengarah \\ Ir.M. Saleh Al Amin,M.T (Wakil Dekan I) \\ Adiguna,S.T,M.Si ( Wakil Dekan II) \\ Aan Sefentry,S.T,M.T ( Wakil Dekan III) \\ Pimpinan Editorial \\ Husnah ,S.T,M.T \\ Dewan Editorial \\ Ir.Muhammad Bakrie,M.T \\ Muhrinsyah Fatimura,S.T,M.T \\ Rully Masriatini,S.T,M.T \\ Nurlela,S.T,M.T \\ Marlina,S.T,M.T \\ Reno Fitrianti,S.T,M.Si \\ Andriadoris Maharanti,S.T,M.T \\ Ir.Agus Wahyudi.M.M
}

\section{Mitra Bestari}

Dr.Erfina Oktariani,S.T,M.T ( STMI Kementerian Perindustrian RI)

Dr.Rer.nat. Risfidian Mohadi, S.Si., M.Si (Universitas Sriwijaya).

Dr. Eko Ariyanto, M.Eng, Chem (Universitas Muhamadiyah Palembang)

Daisy Ade Riany Diem, ST., MT. (Sekolah Tinggi Teknologi Wastukancana)

\section{Staff Editor}

Endang Kurniawan,S.T

Yuni Rosiati,S.T

\section{Alamat Redaksi :}

Program Studi Teknik Kimia Universitas PGRI Palembang

Jalan Jend. A. Yani Lorong Gotong Royong 9/10 Ulu Palembang Sumatera Selatan

Telp. 0711-510043 Fax. 0711-514782 e-mail : tekim.upgri@gmail.com 


\section{JURNAL REDOKS}

Volume 1, Nomor 2, Juli - Desember 2016

\section{DAFTAR ISI}

Artikel Penelitian

Halaman

1. Pengolahan Air Limbah Pewarna Sintetis Untuk Menurunkan Kadar COD Dan Warna Dengan Metode Adsorpsi. (Nurlela) .................................................. 1-5

2. Penurunan Kadar Fenol Dalam Limbah Cair Industri Tenun Songket Dengan Proses Elektrokoagulasi (Atikah) 6-15

3. Penerapan Produksi Bersih Pada Industri Pulp dan Kertas. (Reno Fitrianti)... 1625

4. Studi Pengaruh Proses Pengintegrasian Panas Terhadap Konversi Amoniak Pada Intercooler Reaktor Amoniak Pusri II Dengan Analisis Pinch. (Desy Rosarina) 26-34

5. Pembuatan Biodiesel Dari Minyak Jelantah Dengan Variasi Penambahan Katalis KOH Pada Proses Transesteriikasi. (Muhrinsyah Fatimura, Daryanti, Santi). 3543

6. Evaluasi Kinerja Filter Keramik Pada Pengolahan Air Sungai Musi Berdasarkan Fluks Membrane. (Husnah). 44-49

7. Pengaruh Waktu Dan Massa Zat Asam Benzoate Terhadap Kadar Vitamin C Dalam Pembuatan Sirup Mangga. (Rully Masriantini) 50-55

Petunjuk Untuk Penulisan .$i i i$

Daftar Pustaka .$i v$ 


\title{
Petunjuk Untuk Penulis
}

\section{A. Naskah}

Naskah yang diajukan oleh penulis harus diketik dengan komputer menggunakan bahasa Indonesia yang baik dan benar, menyertakan 1 (satu) soft copy dalam bentuk CD. Penulisan memakai program Microsoft Word dengan ukuran kertas A4, jarak 1,15 spasi.

Naskah yang diajukan oleh penulis merupakan naskah asli yang belum pernah diterbitkan maupun sedang dalam proses pengajuan ditempat lain untuk diterbitkan, dan diajukan minimal 1 (satu) bulan sebelum penerbitan.

\section{B. Format Penulisan Artikel \\ Judul}

Judul ditulis dengan huruf besar, nama penulis tanpa gelar, mencantumkan instansi asal, email dan ditulis dengan huruf kecil menggunakan huruf Times new Roman 11.

\begin{abstract}
Abstrak
Abstrak ditulis dalam bahasa Indonesia antara 100-250 kata, dan berisi pernyataan yang terdapat dalam isi tulisan, menyatakan tujuan dari penelitian, prosedur dasar (pemilihan objek yang diteliti, metode pengamatan dan analisis), ringkasan isi dan kesimpulan dari naskah menggunakan huruf Time New Roman 11, spasi 1,15.

\section{Kata Kunci}

Minimal 3 (tiga) kata kunci ditulis dalam bahasa Indonesia

\section{Isi Naskah}

Naskah ditulis menggunakan huruf Times New Roman 11. Penulisan dibagi dalam 5 (lima) sub judul, yaitu Pendahuluan, Kajian Pustaka, Metode Penelitian, Hasil Pembahasan dan Kesimpulan. Penulis menggunakan standar Internasional (misal untuk satuan tidak menggunakan feet tetapi meter, menggunakan terminalogi dan simbol diakui international (Contoh hambatan menggunakan simbol R). Bila satuan diluar standar SI dibuat dalam kurung $($ misal $=1$ Feet $(\mathrm{m})$ ). Tidak menulis singkatan atau angka pada awal kalimat, tetapi ditulis dengan huruf secara lengkap, Angka yang dilanjutkan dengan simbol ditulis dengan angka Arab, misal 3cm, 4kg. Penulis harus secara jelas menunjukkan rujukan dan sumber rujukan secara jelas.
\end{abstract}

\section{Daftar Pustaka}

Rujukan / Daftar pustaka ditulis dalam urutan angka, tidak menurut alpabet, dengan ketentuan 
seperti dicontohkan sbb :

1. Standar Internasional :

IEC 60287-1-1 ed2.0; Electric cables - Calculation of the current rating - Part 1 - 1: Current rating equations (100\% load factor) and calculation of losses - General. Copyright (C) International Electrotechnical Commission (IEC) Geneva, Switzerland, www.iec.ch, 2006

2. Buku dan Publikasi :

George J Anders; Rating of Electric Power Cables in Unfavorable Thermal

Environment. IEEE Press, 445 Hoes Lane, Piscataway, NJ 08854, ISBN 0-471- 67909-7, 2005.

3. Internet :

Electropedia; The World's Online Electrotechnical Vocabulary.

http://www.electropedia.org, diakses 15 Maret, 2011.

Setiap pustaka harus dimasukkan dalam tulisan. Tabel dan gambar dibuat sesederhana mungkin. Kutipan pustaka harus diikuti dengan nama pengarang, tahun publikasi dan halaman kutipan yang diambil. Kutipan yang lebih dari 4 baris, diketik dengan spasi tunggal tanpa tanda petik. 


\title{
PENURUNAN KADAR FENOL DALAM LIMBAH CAIR INDUSTRI TENUN SONGKET DENGAN PROSES ELEKTROKOAGULASI
}

\author{
Atikah \\ Dosen PNSD Program Studi Teknik Kimia Fakultas Teknik \\ Universitas Muhammadiyah Palembang \\ e-mail : tikaprihatmoko@gmail.com
}

\begin{abstract}
ABSTRAK
Industri tenun songket yang ada di Kota Palembang menghasilkan limbah cair yang berasal dari proses pewarnaan yang umumnya menggunakan pewarna sintetis. Limbah yang dibuang tanpa pengolahan sebelumnya tersebut akan melalui perairan menuju ke Sungai Musi, oleh karena itu perlu dilakukan pengolahan limbah lebih lanjut agar limbah ini aman bagi lingkungan perairan. Penelitian ini bertujuan untuk mengurangi konsentrasi fenol pada limbah cair industri tenun songket sehingga dapat mengurangi beban pencemaran pada perairan Sungai Musi. Parameter yang diamati adalah perubahan konsentrasi fenol. Penelitian dilakukan pada skala laboratorium secara batch dengan menggunakan elektroda aluminium dengan rapat arus $104.17 \mathrm{Am}^{2}, 78.13 \mathrm{~A} / \mathrm{m}^{2}$ dan 62.5 A/m $\mathrm{m}^{2}$. Sampel diambil pada 20, 30, 40, 50 dan 60 menit sejak elektroda mulai dialiri arus listrik. Analisa sampel dilakukan setelah sampel terlebih dahulu diendapkan selama 30 menit. Analisa laboratorium mengacu pada pada SNI 06-6989.2l-2004 untuk parameter fenol. Hasil analisa menunjukkan persentase penurunan konsentrasi fenol tertinggi mencapai $75 \%$ terjadi pada menit ke 60 dengan rapat arus $62.5 \mathrm{~A} / \mathrm{m}^{2}$
\end{abstract}

Kata kunci : limbah cair tenun songket, fenol, elektrokoagulasi

\section{PENDAHULUAN}

Keberadaan industri tekstil di Indonesia tidak hanya dalam kategori industri skala besar dan menengah tetapi juga dalam skala kecil bahkan ada yang dalam skala rumah tangga seperti industri tenun songket yang ada di Kota Palembang. Pembuatan kain songket membutuhkan proses pewarnaan yang umumnya menggunakan pewarna sintetis. Penggunaan zat pewarna sintetis pada kegiatan industri akan membawa dampak pada peningkatan jumlah bahan pencemar dan limbah yang dihasilkannya. Setelah proses pewarnaan selesai akan dihasilkan limbah cair yang berwarna keruh dan pekat yang selain mengandung zat warna juga mengandung bahan-bahan sintetik yang sukar larut atau diuraikan.

Umumnya industri tenun songket ini dilakukan oleh perajin yang berada di kawasan perkampungan padat penduduk. Jika industri tersebut membuang limbah cair maka aliran limbah tersebut akan melalui perairan di sekitar pemukiman yang menuju ke Sungai Musi. Kondisi yang ada di lapangan menunjukkan sebagian besar limbah tidak diolah terlebih dahulu sebelum dibuang ke aliran sungai. Kalaupun ada pengolahan hanyalah pengendapan biasa dengan demikian mutu lingkungan perairan sungai dikhawatirkan menjadi turun. Oleh karena itu perlu dilakukan pengolahan limbah lebih lanjut agar limbah ini aman bagi lingkungan perairan Sungai Musi sebagai badan penerima cemaran. 
Salah satu metode alternative pengolahan limbah cair adalah metode elektrokoagulasi yang memiliki beberapa keuntungan diantaranya dari segi biaya tidak mahal karena disampin galat yang sederhana juga menggunakan bahan yang selalu dapat diperbarui. Energi listrik yang digunakan pun relative kecil karena hanya menggunakan arus listrik DC. Metode elektrokoagulasi membantu penghilangan senyawa organik dan senyawa anorganik yang ada di dalam limbah industry tenun songket.

Penelitian ini bertujuan untuk mengurangi konsentrasi fenol pada limbah cair industri tenun songket sehingga dapat mengurangi beban pencemaran pada perairan Sungai Musi. Permasalahan pada penelitian ini adalah bagaimana mendapatkan kondisi operasi optimum pada pengolahan limbah cair industry tenun songket secara elektrokoagulasi dengan parameter waktu dan rapat arus dan bagaimana perubahan konsentrasi fenol pada limbah setelah melalui proses pengolahan secara elektrokoagulasi. Penelitian ini diharapkan dapat memberikan teknologi alternative elektrokoagulasi untuk mengolah limbah cair industri tenun songket.

\section{KAJIAN PUSTAKA}

\section{Limbah Cair Industri Tenun Songket}

Salah satu proses dalam industri tenun songket yang menghasilkan limbah cair adalah proses pemberian warna atau dyeng yang di samping memerlukan bahan kimia juga memerlukan air sebagai media pelarut. Ini menyebabkan pengendalian dampak lingkungan industri tekstil umumnya terfokus pada limbah cair karena memberikan dampak yang paling luas. Hal ini disebabkan karakteristik fisik maupun kimianya yang memberikan dampak negatif terhadap lingkungan. Sebagian zat-zat yang diperlukan pada proses pemberian warna tersebut teradsorpsi oleh bahan tekstil dan tetap akan berada dalam tekstil sampai proses selesai, sedangkan sisanya berada dalam larutan dan akan terbuang bersama air bekas proses basah. Zat-zat dalam air buangan tersebut berpotensi menimbulkan masalah pencemaran lingkungan (Effendi,2000)

Karakteristik utama dari limbah industri tekstil adalah tingginya kandungan zat warna sintetik, yang apabila dibuang kelingkungan tentunya akan membahayakan ekosistem perairan. Limbah cair industri tenun songket dapat dengan mudah dikenal karena warnanya. Warna selalu jadi kontaminan pertama pada limbah cair. Limbah industry yang berwarna tidak hanya menimbulkan polusi secara visual, tetapi dapat meningkatkan resiko kerusakan lingkungan dan kesehatan (Cascio, 1994). Pada industry tenun songket pewarna yang biasa digunakan adalah pewarna sintetik. Pewarna sintetik banyak digunakan dalam industry tekstil karena memiliki beberapa sifat yang lebih baik dibandingkan dengan senyawa pewarna alami. Keunggulan dari pewarna sintetik adalah mudah diperoleh dengan komposisi yang tetap mempunyai aneka warna, lebih tahan lama, mudah cara pemakaiannya, dan harganya relative murah (Awaluddinet al. 2001).

Molekul zat warna merupakan gabungan dari zat organik tidak jenuh dengan kromofor sebagai pembawa warna dan auksokrom sebagai pengikat warna dengan serat. Zat organik tidak jenuh yang dijumpai dalam pembentukan zat warna adalah senyawa aromatik antara lain senyawa hidrokarbon aromatik dan turunannya, fenol dan turunannya serta senyawa-senyawa hidrokarbon yang mengandung nitrogen. Zat warna tekstil merupakan salah satu pencemar organik yang bersifat non biodegradable. Zat warna tekstil umumnya dibuat dari senyawa azo dan turunannya dari gugus benzen. Diketahui bahwa gugus benzen sangat sulit didegradasi, kalaupun dimungkinkan dibutuhkan 
waktu yang lama. Senyawa azo bila terlalu lama berada di lingkungan, akan menjadi sumber penyakit karena sifatnya karsinogenik dan mutagenik (Soedarsono, 2007)

Proses pewarnaan dan pembilasan menghasilkan air limbah yang berwarna dengan COD tinggi dan bahan-bahan lain dari zat warna yang dipakai, seperti fenol dan logam. Zat warna ini berasal dari sisa - sisa zat warna yang tak larut dan juga dari kotoran yang berasal dari serat alam. Zat warna selain mengganggu keindahan, beberapa juga dapat bersifat racun dan sukar dihilangkan selain itu resisten terhadap degradasi saat nantinya sudah memasuki perairan (Effendi, 2003). Meningkatnya kekeruhan air karena adanya polusi zat warna, nantinya akan menghalangi masuknya cahaya matahari ke dasar perairan dan mengganggu keseimbangan proses fotosintesis, ditambah lagi adanya efek mutagenik dan karsinogen dari zat warna tersebut, membuatnya menjadi masalah yang serius (Eckenfelder,2000).

Tabel 1. Baku Mutu Limbah Cair Industri Tekstil

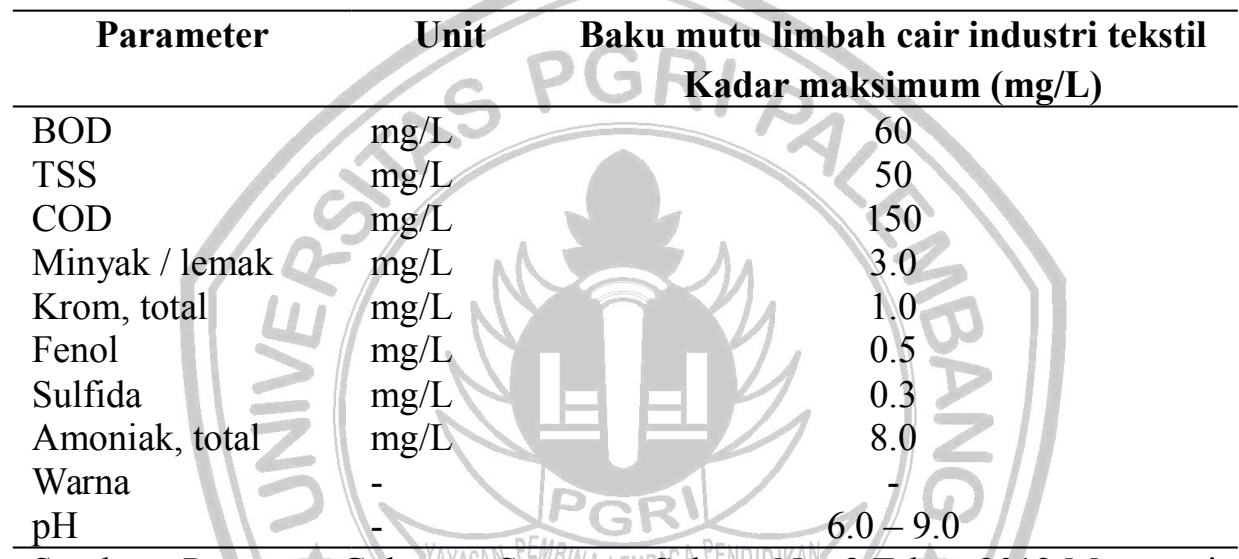

Sumber : Peraturan Gubernur Sumatera Selatan No. 8 Tahun 2012 Mengenai

Baku Mutu Limbah Cair Industri Tekstil

Karakteristik Limbah Cair Songket (Juniar, 2010)

Karakteristik alir limbah songket terdiri dari :

1. Warna

Limbah memiliki intensitas warna yang sangat tinggi, sehingga kalau air limbah itu dibuang ke badan air akan merusak estetika badan air penerima dan badan air yang berwarna pekat akan menyebabkan tembusnya sinar matahari berkurang sehingga proses fotosintesis dalam air akan terhalangi. Hal ini akan menyebabkan kehidupan air terancam punah serta apabila zat warna yang digunakan mengandung logam berat, biota air akan teracuni dan dalam jangka lama akan meresap ke sumur-sumur penduduk yang akhirnya akan mencemari sumur sekitar.

2. Percemaran yang mengambang.

Adanya pencemar yang mengambang pada badan air menyebabkan badan air tertutup oleh lapisan yang mengambang dan akan menghambat tumbuhan, tanah, air terutama adanya minyak akan menyebabkan gangguan pada kehidupan air.

3. Zat tersuspensi.

Zat pencemar ini bisa berupa zat organik maupun anorganik yang mempunyai diameter partikel lebih besar dari 1 mikron. Padatan jenis ini dapat mengendap tanpa bantuan koagulasi tapi waktu yang dibutuhkan relatif lama. Padatan tersupensi organik yang terdekomposisi di dalam badan air 
akan menyebabkan oksigen terlarut berkurang. Hal ini karena oksigen yang ada digunakan untuk penguraian.

4. Koloid

Padatan koloid merupakan padatan dengan ukuran antara 1 milimikron - 1 mikron dan tidak terendapkan tanpa koagulan. Pada umumnya zat-zat koloid teroksidasi secara biologi atau digumpalkan terlebih dahulu dengan zat-zat koagulan kemudian baru diendapkan.

5. Padatan terlarut.

Padatan ini terdiri dari asam, basa, logam berat dan bermacam-macam bahan organik yang menyebabkan badan air penerima tidak bisa dimanfaatkan dan membahayakan kehidupan air. Konsentrasi yang sangat kecil dari bahan terlarut seperti fenol akan menimbulkan bau dan rasa pada air, penguraian organik juga akan terjadi sehingga menyebabkan berkurangnya oksigen dan menimbulkan gas yang beracun dan bau pada badan air penerima.

\section{Senyawa Fenol di Perairan}

Fenol atau asam karbolat atau benzenol adalah zat kristaltak berwarna yang memiliki bau khas. Rumus kimianya adalah $\mathrm{C}_{6} \mathrm{H}_{5} \mathrm{OH}$ dan strukturnya memiliki gugus hidroksil (-OH) yang berikatan dengan cincin fenil. Istilah fenol dalam limbah cair tidak hanya terbatas pada $\left(\mathrm{C}_{6} \mathrm{H}_{5} \mathrm{OH}\right)$ tapi bermacam-macam campuran organik yang terdiri dari satu atau lebih gugusan hidroksil. Fenol dengan konsentrasi $0.005 \mathrm{mg} /$ liter dalam air minum menciptakan rasa dan bau bereaksi dengan chlor yang berbentuk chlorophenol. Sumber-sumber fenol terdapat pada industri pengolahan minyak, batubara, pabrik kimia, pabrik resin, pengecoran pabrik kertas, tekstil (Perdana Ginting, 2007).

Fenol merupakan monohidroksida turunan benzen dan bersifat anionik didalam larutan air. Keberadaan fenol dalam air dapat menyebabkan pencemaran, jika dikonsumsi fenol dapat terakumulasi didalam tubuh dan bersifat racun. Selain itu fenol juga dapat terdegrasi menjadi senyawa lain yang bahkan lebih reaktif. Konsentrasi standar maksimal yang ditetapkan oleh Departemen Kesehatan RI untuk fenol adalah 0,001 mg/l (Rahmi, 2007). Fenol juga mudah masuk lewat kulit sehat. Keracunan akut menyebabkan gejala gastro-intestinal, sakit perut, kelainan koordinasi bibir, mulut dan tenggorokan. Dapat pula terjadi perforasi usus, keracunan kronis menimbulkan gejala gastro-intestinal, sulit menelan, dan hipersalivasi, kerusakan ginjal dan hati, dan dapat diikuti kematian (Rahmi,2007).

Fenol dan derivat-derivatnya merupakan polutan yang sangat berbahaya di lingkungan karena bersifat racun dan sangat sulit didegradasi oleh organisme pengurai. Fenol adalah senyawa kimia yang bersifat korosif yang dapat menyebabkan iritasi jaringan, kulit, mata dan mengganggu pernafasan manusia. Fenol termasuk senyawa aromatik yang di alam dapat terakumulasi dalam rantai makanan. Bahan organik aromatik sebagian besar akan ditransformasi oleh mikroorganisme dan akan mengalami degradasi melalui mekanisme ortho pathway atau meta pathway pada kondisi aerob, sedangkan pada kondisi anaerob senyawa aromatik mengalami penambahan gugus karboksil atau hidrosil sebelum reduksi cincin aromatik (Krastanov, 2013). Fenol merupakan penyebab timbulnya rasa pada air (Krastanov, 2013). Fenol dihasilkan dari industri dan bila konsentrasi mencapai $500 \mathrm{mg} / \mathrm{L}$ masih dapat dioksidasi melalui proses biologi, akan tetapi akan sulit penguraiannya apabila telah mencapai kadar yang melebihi $500 \mathrm{mg} / \mathrm{L}$ (Krastanov, 2013). Fenol dan senyawa turunannya adalah senyawa yang menjadi salah satu parameter kualitas air olahan dari limbah cair industri tekstil. Dalam pengelolaan lingkungan, berbagai upaya dilakukan untuk mengurangi pencemaran fenol dan senyawa turunannya 
antara lain dengan metode elektrolisis, oksidasi, ekstraksi, filtrasi melalui membran cair dan metode adsorpsi. (Fatimah, 2006).

\section{Elektrokoagulasi (Johanes, 1978)}

Elektrokoagulasi merupakan suatu proses koagulasi kontinyu dengan menggunakan arus listrik searah melalui peristiwa elektrokimia, yaitu gejala dekomposisi elektrolit dimana salah satu elektrodanya adalah logam. Reaksi kimia yang terjadi pada proses elektrokoagulasi yaitu reaksi reduksi oksidasi, sebagai akibat adanya arus listrik (DC). Pada reaksi ini terjadi pergerakan dari ionion yaitu ion positif (kation) yang bergerak pada katoda yang bermuatan negatif. Sedangkan ion-ion negatif bergerak menuju anoda yang bermuatan positif yang kemudian ion-ion tersebut dinamakan sebagai anion (bermuatan negatif). Dalam proses ini akan terjadi proses reaksi reduksi dimana logamlogam akan direduksi dan diendapkan di kutub negatif, sedangkan elektroda positif akan teroksidasi menjadi logam hidroksida yang berfungsi sebagai koagulan. Elektroda dalam proses elektrokoagulasi merupakan salah satu alat untuk menghantarkan atau menyampaikan arus listrik ke dalam larutan agar larutan tersebut terjadi suatu reaksi (perubahan kimia). Elektroda tempat terjadi reaksi reduksi disebut katoda, sedangkan tempat terjadinya reaksi oksidasi disebut anoda. Reaksi yang terjadi pada elektroda tersebut sebagai berikut :

\section{Reaksi pada Katoda (Johanes, 1978).}

Pada katoda akan terjadi reaksi-reaksi reduksi terhadap kation, yang termasuk dalam kation ini adalah ion $\mathrm{H}^{+}$dan ion ion logam.

1. Ion $\mathrm{H}+$ dari suatu asam akan direduksi menjadi gas hidrogen yang akan bebas sebagai gelembunggelembung gas.

$$
2 \mathrm{H}^{+}+2 \mathrm{e}---\square \mathrm{H}_{2}
$$

2. Jika larutan mengandung ion-ion logam alkali, alkali tanah maka ion-ion ini tidak dapat direduksi dari larutan yang mengalami reduksi adalah pelarut (air) dan terbentuk gas hidrogen $\left(\mathrm{H}_{2}\right)$ pada katoda.

$$
2 \mathrm{H}_{2} \mathrm{O}+2 \mathrm{e}--\mathrm{-} 2 \mathrm{OH}^{-}+\mathrm{H}_{2}
$$

Dari daftar Eo (deret potensial logam/deret volta), maka akan diketahui bahwa reduksi terhadap air limbah lebih mudah berlangsung dari pada reduksi terhadap pelarutnya (air). $\mathrm{K}, \mathrm{Ba}, \mathrm{Ca}, \mathrm{Na}$, $\mathrm{Mg}, \mathrm{Al}, \mathrm{Zn}, \mathrm{Cr}, \mathrm{Fe}, \mathrm{Cd}, \mathrm{Co}, \mathrm{Ni}, \mathrm{Sn}, \mathrm{Pb}, \mathrm{Sb}, \mathrm{Bi}, \mathrm{Cu}, \mathrm{Hg}, \mathrm{Ag}, \mathrm{Pt}, \mathrm{Au}$

3. Jika larutan mengandung ion-ion logam lain, maka ion-ion logam akan direduksi menjadi logamnya dan terdapat pada batang katoda.

Reaksi pada Anoda (Johanes, 1978).

1. Jika anoda yang digunakan logam aluminium yang akan teroksidasi

$$
\mathrm{Al}^{3+}+3 \mathrm{H}_{2} \mathrm{O}
$$

2. Ion $\mathrm{OH}^{-}$dari basa akan mengalami oksidasi membentuk gas oksigen $\left(\mathrm{O}_{2}\right)$

$$
4 \mathrm{OH}^{-}----\square 2 \mathrm{H}_{2} \mathrm{O}+\mathrm{O}_{2}+4 \mathrm{e}
$$

3. Anion-anion lain $\left(\mathrm{SO}_{4}{ }^{2-}, \mathrm{SO}_{3}{ }^{2-}\right)$ tidak dapat dioksidasi dari larutan, yang akan mengalami oksidasi adalah pelarutnya $\left(\mathrm{H}_{2} \mathrm{O}\right)$ membentuk gas oksigen $\left(\mathrm{O}_{2}\right)$ pada anoda:

$$
2 \mathrm{H}_{2} \mathrm{O}-----\square 4 \mathrm{H}^{-}+\mathrm{O}_{2}+4 \mathrm{e}
$$


Dari reaksi-reaksi yang terjadi dalam proses elektrokoagulasi maka pada katoda akan dihasilkan gas hidrogen dan reaksi ion logamnya. Sedang pada anoda akan dihasilkan gas halogen dan pengendapan flok-flok yang terbentuk. Proses elektrokoagulasi dilakukan pada bejana elektrolisis yang di dalamnya terdapat katoda dan anoda sebagai penghantar arus listrik searah yang disebut elektroda, yang tercelup dalam larutan limbah sebagai elektrolit. Karena dalam proses elektrokoagulasi ini menghasilkan gas yang berupa gelembung-gelembung gas maka kotoran-kotoran yang terbentuk yang ada dalam air akan terangkat ke atas permukaan air. Flok-flok terbentuk ternyata mempunyai ukuran yang relatif kecil dan lama kelamaan akan bertambah besar ukurannya (Riyanto,2013).

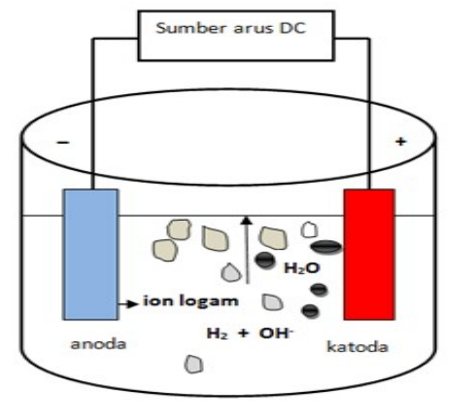

\section{Gambar 1. Prinsip proses elektrokoagulasi}

\section{METODELOGI}

\section{Bahan dan Alat}

Bahan utama yang digunakan dalam penelitian adalah limbah cair industri tenun songket di kawasan Kertapati, Palembang. Alat yang digunakan adalah gelas kimia, beker glass, kabel sumber arus DC, stopwatch, statif, penjepit kabel untuk lempengan katoda dan anoda

\section{Prosedur}

\section{$111 /$}
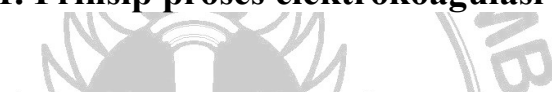

Penelitian ini dilakukan di laboratorium secara batch. Sampel limbah cair industri tenun songket dalam beker glass sebanyak 1 liter dialiri arus listrik 0,5 A, tegangan 12 volt dengan waktu proses 20, 30, 40,50 dan 60 menit. Elektroda yang digunakan adalah aluminium masing-masing berukuran $0.0048,0.0064$ dan $0.008 \mathrm{~m}^{2}$, dengan demikian rapat arus berturut-turut $104.2,78.1$ dan $62.5 \mathrm{~A} / \mathrm{m}^{2}$. Jarak antar elektroda $5 \mathrm{~cm}$. Dari reaksi tersebut akan menghasilkan gas, buih dan flok. Selanjutnya flok yang dihasilkan akan mengikat fenol yang terdapat dalam limbah cair dan flok akan mengendap. Selanjutnya flok yang telah mengikat kontaminan fenol diendapkan selama 30 menit dan sisa buih akan dipisahkan. Karakteristik proses elektrokoagulasi pada penelitian ini ditentukan dengan mengukur kadar fenol. Analisa kadar fenol dilakukan dengan metode pemeriksaan SNI 06-6989.42004.

\section{HASIL DAN PEMBAHASAN}

Apabila dalam suatu elektrolit ditempatkan dua elektrode dan dialiri arus listrik searah maka akan terjadi proses elektrokimia, yaitu dekomposisi elektrolit. Ion positif akan bergerak ke katoda menerima elektron yang direduksi dan ion negatif akan bergerak ke anoda dan menyerahkan elektron yang dioksidasi. 
Proses elektrokimia pada penelitian ini menyebabkan terjadinya pelepasan ion $\mathrm{Al}^{3+}$ dari lempengan elektroda (anoda) dan akan mengikat ion $(\mathrm{OH})^{-}$membentuk flok $\mathrm{Al}(\mathrm{OH})_{2}$ yang akan mengikat kontaminan dan partikel-partikel dalam limbah cair. Pada katoda larutan yang mengalami reduksi adalah pelarut (air) dan terbentuk gas hidrogen $\left(\mathrm{H}_{2}\right)$ pada katoda (Hari dkk, 2010) :

$$
2 \mathrm{H}_{2} \mathrm{O}+2 \mathrm{e} \quad \square \rightarrow 2 \mathrm{OH}^{-}+\mathrm{H}_{2}
$$

Anoda terbuat dari logam almunium yang akan teroksidasi menjadi :

$$
\mathrm{Al}^{3+}+3 \mathrm{H}_{2} \mathrm{O} \quad \square \square \rightarrow \mathrm{Al}(\mathrm{OH})_{3}+3 \mathrm{H}^{+}+3 \mathrm{e}
$$

Ion $\mathrm{OH}^{-}$dari basa akan mengalami oksidasi membentuk gas oksigen $\left(\mathrm{O}_{2}\right)$ :

$$
4 \mathrm{OH}^{-} \square \square \rightarrow 2 \mathrm{H}_{2} \mathrm{O}+\mathrm{O}_{2}+4 \mathrm{e}
$$

Ion aluminium yang dihasilkan dari reaksi anoda bereaksi dengan ion hidroksil membentuk aluminium hidroksida $\mathrm{Al}(\mathrm{OH})_{3}$ yang bersifat gel, yang dapat mengkoagulasi fenol dari larutan secara adsorpsi. (Mohammed, 2007). Gas hidrogen dari katoda membantu flok $\mathrm{Al}(\mathrm{OH})_{3}$ dalam larutan yang terangkat ke permukaan. Ion aluminium yang dilepaskan dari anoda kemungkinan langsung berinteraksi dengan fenol kemudian mengendap dalam bentuk garam tidak larut antara lain aluminium triphenolate [Al(OAr)3] (Weeracai et al, 2002). Mekanisme pengendapan flok $\mathrm{Al}(\mathrm{OH})_{3}$ mengikuti prinsip koagulasi-flokulasi karena adanya pertumbuhan massa flok sehingga berat jenis flok menjadi besar dan akhirnya mengendap. Kondisi ini yang memungkinkan terjadinya penurunan kadar fenol dalam limbah. Pembentukan endapan dan flok-flok yang terapung (flotation) mengindikasikan bahwa $\mathrm{Al}(\mathrm{OH})_{3}$ mengikat polutan atau pengotor dengan efektif.

Pengaruh rapat arus terhadap penurunan konsentrasi fenol dalam air limbah berlangsung pada temperatur $30^{\circ} \mathrm{C}$. Konsentrasi fenol sebelum diolah adalah $0.72 \mathrm{mg} / \mathrm{L}$. Arus listrik searah yang digunakan pada semua perlakuan adalah $0.5 \mathrm{~A}$. Luas elektroda aluminium yang digunakan 0.0048 , 0.0064 dan $0.008 \mathrm{~m}^{2}$.

Tabel 2. Hasil analisa konsentrasi fenol dan persentase penurunan untuk tiap perlakuan

\begin{tabular}{cccc}
\hline $\begin{array}{c}\text { Rapat arus } \\
\left(\mathbf{A} / \mathbf{m}^{\mathbf{2}}\right)\end{array}$ & $\begin{array}{c}\text { Waktu } \\
(\mathbf{m e n i t})\end{array}$ & $\begin{array}{c}\text { Konsentrasi fenol } \\
(\mathbf{m g} \mathbf{l})\end{array}$ & $\begin{array}{c}\text { Penurunan } \\
\text { konsentrasi fenol (\%) }\end{array}$ \\
\hline & 0 & 0.72 & 0 \\
104.2 & 20 & 0.61 & 15.2 \\
& 30 & 0.51 & 29.2 \\
& 40 & 0.45 & 37.5 \\
& 50 & 0.39 & 45.8 \\
& 60 & 0.28 & 61.1 \\
\hline 78.1 & 0 & 0.72 & 0 \\
& 20 & 0.58 & 19.4 \\
& 30 & 0.52 & 27.8 \\
& 40 & 0.40 & 44.4 \\
& 50 & 0.35 & 51.4 \\
62.5 & 60 & 0.22 & 69.4 \\
& 0 & 0.72 & 0 \\
& 20 & 0.49 & 31.9 \\
& 30 & 0.44 & 38.9 \\
& 40 & 0.33 & 54.2 \\
& 50 & 0.23 & 68.1 \\
& 60 & 0.18 & 75.0 \\
\hline
\end{tabular}

Hasil analisis limbah cair industri tenun songket setelah melalui proses elektrokoagulasi dengan elektroda $\mathrm{Al}$ menunjukkan perubahan konsentrasi fenol yang signifikan. Analisa awal limbah 
sebelum pengolahan adalah $0.72 \mathrm{mg} / \mathrm{L}$. Data pada Tabel 2 menunjukan bahwa rapat arus dan waktu proses berpengaruh terhadap penurunan kadar fenol dalam limbah cair. Semakin besar luas permukaan eletroda yang digunakan dan semakin lama waktu proses maka penurunan konsentasi fenol makin besar (Yulianto dkk, 2009). Hal ini disebabkan waktu dan rapat arus mempengaruhi banyak ion $\mathrm{Al}^{3+}$ yang terlarut. Al terlarut berperan sebagai koagulan yang berfungsi sebagai pembentuk flok $\mathrm{Al}(\mathrm{OH})_{3}$ untuk mengikat kontaminan dan partikel-partikel dalam limbah.

Dari data Tabel 2 dapat dilihat bahwa pada rapat arus $104.2 \mathrm{~A} / \mathrm{m}^{2}$ dan lama proses 20 - 60 menit didapat penurunan konsentrasi fenolsebesar 15.2-61.1\%. Dengan rapat arus $78.1 \mathrm{~A} / \mathrm{m}^{2}$ penurunan yang dapat dicapai $19.4-69.4 \%$ dalam waktu proses yang sama. Penggunaan rapat arus $62.5 \mathrm{~A} / \mathrm{m}^{2}$ menghasilkan penurunan konsentrasi fenol sebesar 31.9 - $75 \%$ juga dalam waktu 20 - 60 menit. Meningkatnya luas permukaan elektroda menyebabkan ion yang dihasilkan anoda dan katoda meningkat sehingga meningkatkan pembentukan flok-flok dalam larutan. Juga jumlah gelembung meningkat mengakibatkan ukuran gelembung mengecil, hal ini berhubungan dengan kenaikan momentum flux dan peningkatan pencampuran (Mohammed,2007).

Gambar 2 menunjukan hubungan antara penurunan konsentrasi fenol dan waktu pada tiap rapat waktu Pada penelitian ini penurunan terbesar konsentrasi fenol dalam limbah terjadi pada waktu proses 60 menit dan rapat arus $62.5 \mathrm{~A} / \mathrm{m}^{2}$ yaitu menghasilkan penurunan sebesar $75 \%$ dengan hasil $0.18 \mathrm{mg} / \mathrm{L}$.

Elektroda dengan luas $0.008 \mathrm{~m}^{2}$ dan rapat arus $62.5 \mathrm{~A} / \mathrm{m}^{2}$ memiliki efek penurunan konsentrasi fenol yang lebih baik dibandingkan dua elektroda lain yang lebih kecil. Hal ini dikarenakan permukaan elektroda yang lebih besar mengakibatkan dispersi gelembung lebih banyak dalam reaktor (Mohammed, 2007). Dengan meningkatnya dispersi gelembung dalam reaktor, kemungkinan tumbukan antara gelembung dan koagulan meningkat yang mengakibatkan penurunan konsentrasi fenol makin besar.

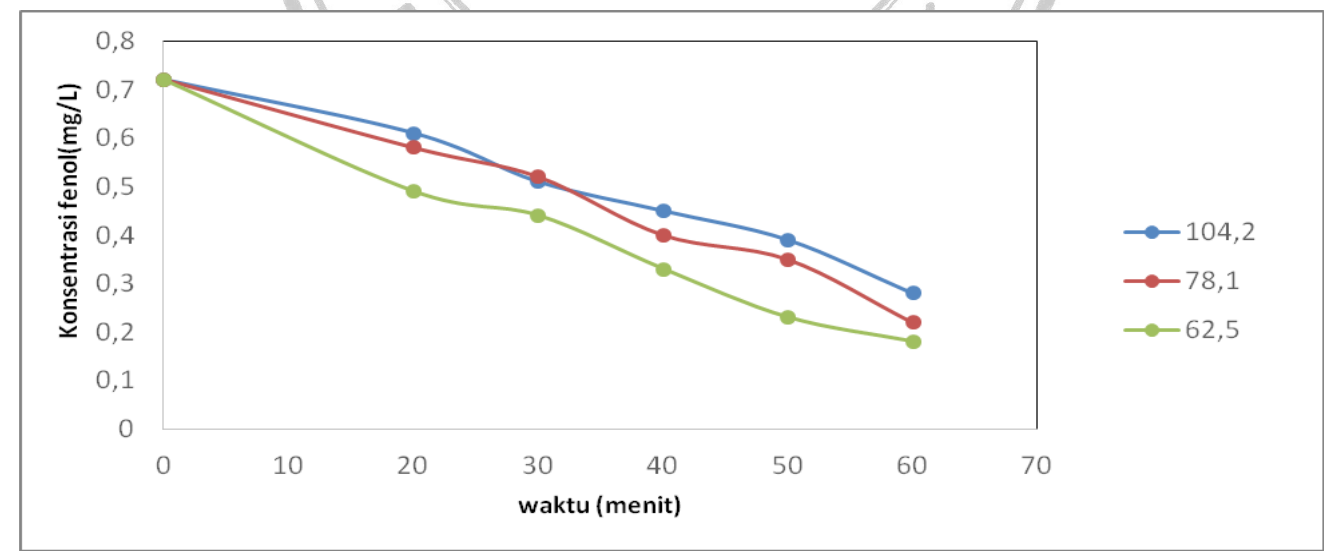

\section{Gambar 2. Grafik hubungan konsentrasi fenol dan waktu pada tiap rapat arus}

Dari Gambar 2 dan 3 terlihat bahwa waktu proses yang digunakan sangat mempengaruhi penurunan kadar fenol. Hal ini terjadi karena semakin lama waktu yang digunakan pada proses elektrokoagulasi semakin banyakion $\mathrm{Al}^{3+}$ terlarutdan gas hidrogen yang terbentuk. Al terlarut berperan sebagai koagulan yang berfungsi sebagai pembentuk flok $\mathrm{Al}(\mathrm{OH})_{3}$ untuk mengikat kontaminan dan partikel-partikel dalam limbah.

Penurunan kadar fenol yang terlihat sangat signifikan terjadi pada waktu proses 20 menit. Hasil analisa kadar fenol untuk proses elektrokoagulasi yang lebih lama dari 20 menit menunjukan 
kecenderungan untuk terus turun tetapi perbedaannya tidak terlalu besar. Setelah 20 menit efisiensi penghilangan fenol menurun karena pada kondisi yang sama flok-flok dan hidrogen telah konstan sehingga menurunkan kapasitas adsorpsi dan laju flotasi. Pada 20 menit pertama, kapasitas adsorpsi flok belum menurun dan dengan bertambahnya waktu, terjadi desorpsi dalam larutan yang mengakibatkan penurunan efisiensi penghilangan fenol (Mohammed, 2007)

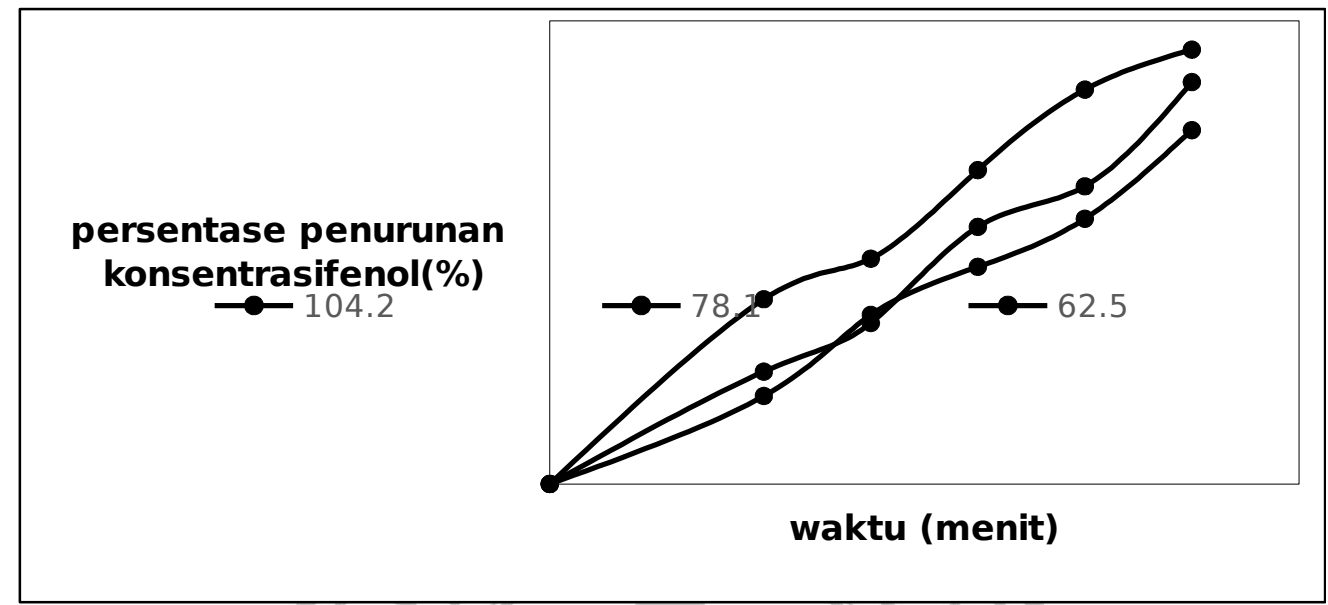

Gambar 3. Grafik hubungan persentase penurunan konsentrasi fenol dan waktu pada tiap rapat arus

Setelah 20 menit elektroda mulai menuju pada keadaan jenuh dan medan magnet yang terjadi sudah sangat kecil maka proses elektrokimia mulai menurun sampai proses elektrokoagulasi tidak terjadi lagi, sehingga kadar fenol dalam limbah akan tetap. Proses elektrokoagulasi mencapai titik terendah pada saat lempengan elektroda tidak menimbulkan medan magnet (Susetyaningsih, 2008).

\section{KESIMPULAN}

Hasil penelitian memberikan kesimpulan bahwa proses elektrokoagulasi dapat digunakan pada pengolahan limbah cair industry tenun songket karena mampu menurunkan kadar fenol dalam limbah. Persentase penurunan konsentrasi fenol dipengaruhi waktu dan rapat arus. Hal ini berkaitan dengan hubungan antara peningkatan flok-flok dan hidrogen. Kondisi terbaik pada percobaan ini dicapai pada waktu proses elektrokoagulasi selama 60 menit dan rapat arus $62.5 \mathrm{~A} / \mathrm{m}^{2}$, yaitu memberikan penurunan konsentrasi fenol sebesar $75 \%$ sehingga kadar fenol yang masih ada dalam limbah adalah $0.18 \mathrm{mg} / \mathrm{L}$. Nilai ini lebih rendah dari batasan yang ditetapkan oleh Peraturan Gubernur Sumatera Selatan No. 8 Tahun 2012 Mengenai Baku Mutu Limbah Cair Industri Tekstil dimana kadar fenol yang diizinkan untuk air bersih adalah $0.5 \mathrm{mg} / \mathrm{l}$, sehingga bila ditinjau dari parameter fenol, limbah cair ini sudah cukup aman untuk dialirkan kebadan sungai.

\section{DAFTAR PUSTAKA}

Awaluddin R, Darah S, Ibrahim C.D.and Uyub A.M. Decolorization of commercially Available Synthetic Dyes by The White Rot Fungus Phanerohaete Chrysosporium. Journal Fungi and Bactery. 2001.

Cascio,J. International Environmental Management Standards in Electronicand and The Enviroment. Proceeding IEEE International Symposium. 1994 
Eckenfelder, W, Wesley. Industrial Water Pollution Control. Third Edition. Mc Graw HillInternational Edition. New York.2000

Effendi, H. Telaah Kualitas Air. IPB. Bogor. 2000

Effendi, H. Telaah Kualitas Air bagi Pengelolaan Sumber Daya Alam dan Lingkungan Perairan. Kanisius. Yogyakarta. 2003

Fatimah Is, Kamalia, Tahir I., Sugiarto, E.,Wijaya K.Utilisasi TiO2, Zeolit dan Sinar UV untuk Fotodegradasi Zat Warna Congo Red. Indonesia Journal of Chemistry. 2006

Hari P, Bambang, Harsanti, Mining. Pengolahan Limbah Cair Tekstil Menggunakan Proses Elektrokoagulasi dengan Sel Al-Al. Prosiding Seminar Nasional Teknik Kimia "Kejuangan”. Yogyakarta, 26 Januari 2010.

Juniar, Heni. Observasi Tinggi Unggun Adsorben Karbon dan Debit terhadap Pengolahan Limbah Cair Songket. Jurnal Berkala Teknik Vol. 2 No. 2. 2012

Johanes, H. Listrik dan Magnet. Balai Pustaka. Jakarta.1978

Krastanov A., Alexieva Z., Yemendzhiev H.. Microbial Degradation of Phenol and Phenolic Derivatives. Journal Engineering in Life Science. Volume 13 Issue 1.2013

Mohammed, Ahmed A. Electrocoagulation of Phenol for Wastewater Treatment Iraqi Journal of Chemical and Petroleum Engineering. Vol.9 No.3 December 2007.ISSN: 1997-4884

Peraturan Gubernur Sumatera Selatan No. 8 Tahun 2012 Mengenai Baku Mutu Limbah Cair Industri Tekstil

Perdana Ginting. Sistem Pengelolaan Lingkungan dan Limbah Industri. Bandung: Yrama Widya. 2007.

Rahmi. Adsorpsi Fenol pada Membran Komposit Khitosan Berikatan Silang. Jurnal Rekayasa Kimia dan Lingkungan. Vol. 6, No. 1, hal. 28-34, 2007.

Riyanto. Elektrokimia dan Aplikasinya. Graha Ilmu. Yogyakarta. 2013

Soedarsono, Benny Syahputra. Pengolahan Air Limbah Batik dengan Proses Kombinasi Elektrokimia, Filtrasi, dan Adsorbsi. 2007. ( http://bennysyah.edublogs.org/files/2007/04/makalahwarna-akin.doc. Diakses 1 Desember 2016)

Susetyanigsih, Retno dkk. Kajian Proses Elektrokoagulasi untuk Pengolahan Limbah Cair. Prosiding Seminar Nasional IV SDM Teknologi Nuklir 25 - 26 Agustus 2008. Yogyakarta.

Weerachai, P.,Sombat,C and Duang,B.Electrocoagulation and subsequent Recovery of Phenolic Compounds. Japan Society for Analytical Chemistry. October Vol 16. 2002.

Yulianto, Andik dkk. Pengolahan Limbah Cair Industri Batik pada Skala Laboratorium dengan Menggunakan Metode Elektrokoagulasi. Jurnal Teknologi Lingkungan Vol. 5 No. 1.2009 